\title{
IMPLEMENTASI KONSERVASI KELELAWAR BERKELANJUTAN DI DESA OLIBU PROVINSI GORONTALO
}

\section{IMPLEMENTATION OF SUSTAINABLE BAT CONSERVATION IN THE OLIBU VILLAGE OF GORONTALO PROVINCE}

\author{
Safriyanto Dako ${ }^{* 1)}$, Nibras K. Laya ${ }^{1)}$, Netty Ino (schak $^{2)}$ Frida M. Yusuf ${ }^{2)}$, Frimawaty H. Djafar ${ }^{3)}$, \\ Suleman Daima ${ }^{4)}$ \\ ${ }^{1}$ Jurusan Peternakan Fakultas Pertanian Universitas Negeri Gorontalo, \\ ${ }^{2}$ Fakultas Matematika dan IImu Pengetahuan Alam Universitas Negeri Gorontalo \\ ${ }^{3}$ Lembaga Pemerhati lingkungan, Provinsi Gorontalo \\ ${ }^{4}$ Pemerintah Desa Olibu, Boalemo, Gorontalo \\ Jalan Jendral Sudirman Nomor 6, Kota Gorontalo, 96128 \\ Alamat korespondensi : sdako@ung.ac.id
}

(Tanggal Submission: 15 Januari 2020, Tanggal Accepted: 15 April 2020)

\begin{abstract}
ABSTRAK
Konservasi kelelawar memberikan dampak yang positif baik terhadap keberlanjutan perkembangbiakan nya maupun terhadap kondisi sosial ekonomi masyarakat. Kegiatan pengabdian kepada masyarakat ini bertujuan untuk memberikan pemahaman kepada Kelompok masyarakat pemanfaat kelelawar tentang penerapan konservasi kelelawar berkelanjutan. Metode pelaksanaan melalui Penetapan wilayah konservasi in-situ, pembinaan Kelompok Pemanfaat Kelelawar melalui Model PRA, dan pengawasan wilayah konsevasi. Kegiatan ini dilaksanakan di Desa Olibu, Kabupaten Boalemo, Provinsi Gorontalo. Kelompok sasaran adalah Kelompok Pemanfaat Kelelawar yang berada di desa Olibuu, terdiri atas: Kelompok Accerodon, dan Alecto. Implementasi konservasi kelelawar didesa Olibu telah ditetapakan kawasan hutan manggorve sebagai kawasan konservasi In-situ bagi satwa kelelawar. Pengawasan wilayah konservasi dilakukan secara terpadu bersama masyarakat. Pembinaan kelompok memberi dampak terhadap peningkatan pengetahuan bagi Kelompok Pemanfaat Kelelawar. Tercapainya kesepakatan antara kelompok, Pemerintah Desa, Pemerintah Kecamatan, Perwakilan Masyarakat, dan Universitas Negeri Gorontalo tentang inplementasi konservasi kelelawar di Desa Olibu: Larangan penebangan hutan Mangrove, Larangan menggunakan senjata api atau sejenisnya untuk berburu kelelawar, Frekuensi menangkap kelelawar di lokasi in-situ di kurangi (2 kali dalam seminggu), dengan cara menggunakan Mist Net, dan dilakukan pada pukul 03.00 - 05.00, sortasi kelelawar, dengan kriteria: kelelawar yang berukuran kecil, bunting dan menyusui anak, dilepaskan kehabitatnya.
\end{abstract}

Kata kunci: Konservasi, Kelelawar, In-situ, ex-situ, kelompok pemanfaat kelelawar, Gorontalo

\section{PENDAHULUAN}

Satwa liar atau Wildlife merupakan sumber daya alam yang dapat diperbaharui (renewable resource), melalui pengelolaan yang berwawasan lingkungan dan berkelanjutan (Wulandari, 2011). Kelelawar merupakan satwa liar, yang memilik peranan penting bagi manusia dan ekosistem di alam, akan tetapi populasinya terus mengalami penurunan, bahkan beberapa jenis dinyatakan telah punah (Falcao et al, 2003). Kelelawar jelas berbeda dengan mamalia lainnya karena mempunyai sayap dan mempunyai kemampuan terbang (Payne et al, 2000), dan komponen yang penting dalam biodiversitas. Kelelawar terdiri atas 1111 spesies yang tersebar di belahan bumi (Simmon, 2008), terdapat 18 suku 
yang terdiri atas 970 spesies. Ada 9 suku yang terdiri atas 205 spesies kelelawar di Indonesia.

Pulau Sulawesi merupakan salah satu tempat hidup kelelawar, berbagai jenis dengan ukuran relatif besar, sampai jenis yang terkecil di dunia (Heinrichs, et al.,1997). Pteropus alecto (Black flying fox) dan Acerodon Selebensis, kedua spesis inihidup dan tersebar di beberapa habitat hutan hujan tropis di Sulawesi Utara, Gorontalo dan Sulawesi tengah, Sulawesi Selatan, Sulawesi tenggara, Sulawesi barat dan berstatus endemic dan terancam kepunahan. (Ransaleleh, 2013).

Potensi keberadaan kelelawar di desa Olibu menjadi daya tarik tersendiri bagi masyarakat luar didesa Olibu. Pemanfaatan satwa ini oleh kelompok masyarakat sebagai tambahan ekonomi, disaat masa paceklik dan kondisi lautan yang tidak bersahabat (gelombang tinggi). Perselisihan antar kelompok masyarakat pemanfaat kelelawar selalu terjadi bahkan hingga berurusan dengan masalah hukum disebabkan pemanfaatan hewani. Metode penangkapan yang berbeda setiap kelompok menjadi permasalahan utama. Perburuan kelelawar menggunakan senjata api, ranjau pancing, dan layang-layang menyebabkan terganggunya aktivitas kelelawar saat beristrahat, kawin dan interaksi antar kelelawar sehingga pada akhirnya kelelawar menjadi sangt liar dan akhirnya meninggalkan habitatnya. Konservasi kelelawar berkelanjuitan sangat penting dilakukan guna keberlanjutan hidup satwa ini tanpa mengurangi nilai ekonomis bagi kelompok masyarakat pemanfaat yang ada didesa olibu. Program Pengabdian Desa Mandiri (PPDM) sebagai motivator utama pengembangan dan kemandirian desa, menjadikan desa Olibu sebagai desa konservasi kelelawar berkelanjutan.

\section{METODE PELAKSANAAN}

\section{Mitra atau Kelompok Sasaran}

Mitra adalah Kelompok pemanfaat Kelelwar yang berada di desa Olibuu, Kecamatan Paguyaman Pantai, Kabupaten Boalemo, Provinsi Gorontalo. Mitra ini terdiri atas 2(dua) kelompok: Kelompok accerodon (1) dan kelompok Alecto(2), masing masing kelompok terdiri atas 8-10 orang anggota.

\section{Teknik pelaksanaan}

Implementasi

konservasi

kelelawar

dilakukan dengan cara:

1. Penetapan Lokasi Konservasi Kelelawar: melalui survey dan pengamatan langsung bersama Tim PPDM, Kelompok Pemanfaat Kelelawar, Pemerintah Desa Olibu.

2. Program Penanaman tanaman buah. Penanaman tanaman buah dilakukan di wilayah eks-situ rawan becana,

3. Program edukasi dilakukan dengan model pembelajaran orang dewasa (PRA), dimana ini, kelompok dan anggota sebagai objek untuk mendapatkan edukasi, sehingga permasalahan yang dihadapi kelompok dapat terungkap, sehingga mediasi dapat dilakukan, selain itu pembinaan kelompok pemanfaat dalam peningkatan ketrampilan

4. Pengawasan terpadu di kawasan in-situ.

\section{HASIL DAN PEMBAHASAN}

\section{Kondisi wilayah Desa Olibu}

Desa Olibuu adalah desa yang terletak di wilayah pesisir pantai selatan, kabupaten Bualemo, Provinsi Gorontalo. Desa olibu bagian barat berbatasan dengan desa Apitalo, timur berbatasan dengan Desa Girisa. Kab. Gorontalo, bagian utara berbatasan dengan Desa Tangkobu dan selatan berbatasan dengan Teluk tomini. Jumlah penduduk 684 orang, jumlah Kepala kelauarga; $154 \mathrm{KK}$, potennsi utama desa adalah pertanian dan perikanan, sedangkan pendidikan tidak tamat sekolah SD 332 orang, tamat SD 286 orang, SMP 106 orang, SLTA 180, SI 3 orang (Kecamatan Paguyaman Pantai dalam angka, 2018).

\section{Penetapan kawasan Insitu dan Ex-situ}

Berdasarkan hasil pengamatan tim PPDM dan wawancara bersama kelompok pemanfaat kelelawar, Masyarajkat, dan Pemerintah Desa Olibu. Desa Olibu memiliki $3 / 4$ kawasan mangrove yang membentang sepanjang garis pantai bagian Timur dan barat, kawasan mangrove dipantai bagian barat dihuni oleh satwa kelelawar (Accerodon Selebensi dan Pterophus Alecto). Wilayah mangrove ini ditetapkan sebagai kawasan in-situ, hal ini didasarkan keberadaan kelelawar yang menetap, istrahat, kawin dan melahirkan. Satwa kelelawar ini menempati kawasan 
mangrove sepanjang tahun namun jika frekuensi perburuan menggunakan senjata api, jerat kail dan layang-layang meningkat maka satwa ini akan bermigrasi, dan untuk kembali harus menunggu 6 bulan - 1 tahun. Kelelawar sangat rentan dan bergantung pada daya dukung lingkungan. Kerentanan ini disebabkan sifat dan produktivitasnya rendah, lamanya waktu asuh, dan perkembangan yang lamban, seluruh adaptasi untuk bertahan hidup pada habitat yang stabil dan mudah diprediksi, serta populasi yang dipertahankan untuk tetap berada dalam daya dukung lingkungannya (Kunz \& Peirson 1994, Purvis et al. 2000). Kelelawar menempati hutan mangrove selama siang hari, di malam hari keluar mencari makan di Cagar alam Nantu (Boliohuto), Taman Nasional Bogani, pemukiman penduduk bahkan lahan perkebunan milik petani.

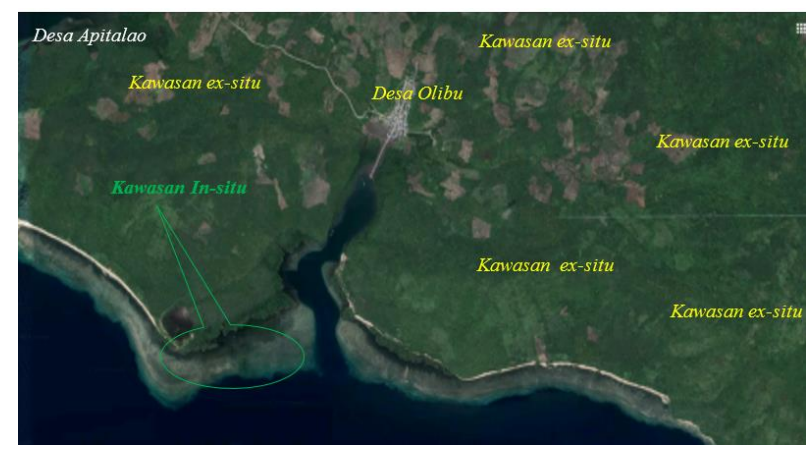

Gambar 1. Kawasan Konservasu dan kawasan in-situ

\section{Progran Penanaman Tanaman buah}

Berdasarkan hasil survei tim PPDM di Desa Olibu, kondisi lahan pertanian adalah lahan kering, dan berbukit, lereng, tingkat kemiringan lahan 30o-65o. Kondisi tanah seperti ini menurut Arsyad (2000) mudah terjadi erosi dan perngendalian erosi dapat dilakuakan secara vegetatif

Penanaman tanaman buah dilakukan oleh Tim PPDM, Kelompok, Pemerintah Desa Olibu dan berkolaborasi dengan Mahasiswa KKS, penanaman diwilayah ex-situ yang berpotensi terjadinya longsor, sepanjang pinggiran jalan didesa, dan di wilayah perkebunan miliki masyarakat. Penanamaan tanaman buah bertujuan untuk penyediaan kebutuhan sumber pakan bagi satwa kelelawar dalam kawasan konservasi, selain itu menjadi salah satu solusi pencegahan erosi tanah dan mengembalikan kondisi tanah, dan dapat benilai ekonomi untuk kelompok dan masyarakat.
Bibit buah yang ditanam adalah buah popaya, rambutan, duku. dan durian.

Tanaman pekebunan seperti kopi, teh, kina, dan berbagai jenis buah-buahan juga banyak diproduksi di lahan pegunungan. Lahan pegunungan yang merupakan hulu DAS juga berperan penting dalam menjaga tata air DAS itu sendiri, mempertahankan keanekaragaman hayati, mengendalikan erosi, dan menambat karbon di atmosfer sehingga mengurangi pemanasan global (Departemen Pertanian, 2006)

\section{Edukasi Program Dasar Konservasi}

Program pembinaan kelompok bertujuan peningkatan pengetahuan melalui proses belajar orang dewasa. Penerapan edukasi dapat meningkatkan pengetahuan terhadap kelompok mitra dan masyarakat tentang keberadaan, fungsi ekologis kelelawar dan konservasi satwa kelelawar berkelanjutan.

Berdasarkan tabel 1 hasil penilaian pretest dan post-test terhadap pengetahuan kelompok dan anggota, memberikan gambaran peningkatan pengetahuan, terdapat 4 orang (25\%) memiliki pengetahuan baik, sebanyak 5 orang (31.25\%) memiliki pengetahuan cukup berjumlah 5 orang (31.25\%), 6 orang $(37,13 \%)$ memiliki pengetahuan kurang, dan terdapat 1 orang yang memiliki tingkat pengetahuan buruk (6.25\%). Kondisi ini disebabkan karena anggota kelompok memiliki pendidikan yang rendah dan kemampuan ekonomi lemah. Peningkatan pengetahuan setelah adanya edukasi tergambarkan dalam tabel 1 , adanya peningkatan pengetahuan untuk kategori baik sebanyak 7 orang (43.75\%) dan kategori cukup sebanyak 9 orang (56.52\%)

Berdasarkan uji beda tingkat pengetahuan kelompok pemanfaat kelelawar meningkat 0.81 point setelah edukasi. Edukasi tentang status kelelawar dan konservasi berkelanjutan sangat penting diketahui kelompok dan anggotanya guna pelestarian satwa, peningkatan ekonomi kelompok dan anggota serta bahaya penyebaran virus BAT Cov yang bersifat zoonosis bagi pemanfaat satwa ini, menyebabkan gangguan pernapasan 
Tabel 1. Pengetahuan kelompok dan anggota berdasarkan total nilai pre-test dan post-test

\begin{tabular}{lcccc}
\hline \multirow{2}{*}{ Pernilaian } & \multicolumn{2}{c}{ Pre-tes } & \multicolumn{3}{c}{ Post tes } \\
\cline { 2 - 5 } & Frekuensi & $\%$ & Frekuensi & $\%$ \\
\hline Baik & 4 & 25 & 7 & 43.75 \\
Cukup & 5 & 31.25 & 9 & 56.52 \\
Kurang & 6 & 37.13 & 0 & 0 \\
Buruk & 1 & 6.25 & 0 & 0 \\
\hline
\end{tabular}

Keterangan : \% = prosentase

Menurut W.D Febriani et al (2018) dan Pamungkas et.al., (2018) kelelawar yang ada di Provinsi Gorontalo positif virus Bat CoV. (virus korona). Lebih lanjut di sampaikan Coronavirus Sindrom Pernafasan Akut Parah ini ditemukan pada tahun 2003 dan Koronavirus Pernafasan Sindrom Timur-Timur (Mers-CoV) pada tahun 2012 yang menginfeksi lebih dari 8000 orang di dunia dan menyebabkan 774 kematian. Pelaksanaan edukasi bagi kelompok pemanfaat kelelawar harus dilakukan secara berkesinambungan guna perubahan pola pikir dari kelompok tersebut, karena tingkat pengetahuan dari kelompok dan anggota kelompok sangat rendah (Kecamatan Paguyaman Pantai dalam angka, 2018).

Tabel 2 Pengaruh edukasi terhadap pengetahuan

\begin{tabular}{lcccc}
\hline Kegiatan & Nilai terendah & Nilai Tertinggi & Rataan $\pm S D$ & $p$ - vaule \\
\hline Pree-test & 4 & 10 & $7.098 \pm 1.2868$ & 0.0284 \\
Post Test & 6 & 10 & $7.906 \pm 1.0982$ & \\
\hline
\end{tabular}

Pembinaan kelompok juga dihasilkan kesepakatan dasar di wilayah konservasi kelelawar antar kelompok dan masyarakat, ada 4 (empat) kesepakatan dasar di wilayah konservasi:

1. Melarang Penebangan hutan bakau tanpa seizin pemerintah desa Olibu

2. Penangkapan kelelawar dilarang menggunakan senjata api atau sejenisnya yang menyebabkan kematian dan terganggunya habitat kelelawaer dihutan bakau.

3. Frekuensi menangkap kelelawar di lokasi insitu dapat dilakukan 2 kali dalam seminggu, dengan cara menggunakan mist net, dan dilakukan pada pukul 03.00 am -05.00 am.

4. Frekuensi menangkap kelelawar di lokasi insitu dapat dilakukan 2 kali dalam seminggu, dengan cara menggunakan mist net, dan dilakukan pada pukul $03.00 \mathrm{am}-05.00 \mathrm{am}$.

5. Kelelawar yang tertangkap harus disortasi, dengan kriteria: Kelelawar yang masih berumur muda/berukuran kecil, bunting dan kelelawar induk yang mengasuh anak harus dilepaskan kembali kehabitatnya.

Program pemberdayaan kelompok tani harus dapat meningkatkan kemampuan kelompok tani dalam hal: (1) memahami potensi dan kelemahan kelompok, (2) memperhitungkan peluang dan tantangan yang dihadapi pada saat mendatang, (3) memilih berbagai alternatif yang ada untuk mengatasi masalah yang dihadapi, (4) menyelenggarakan kehidupan berkelompok dan bermasyarakat yang serasi dengan lingkungannya secara berkesinambungan (Hermanto dan Swastika, 2011).

\section{Pengawasan Wilayah Konservasi}

Pengawasan merupakan kegiatan yang penting dalam keberlanjutan konservasi. Berdasarkan pertemuan yang dilakukan oleh TIM PPDM ditingkat kelompok, Pemerintah Desa Olibuu dan karang taruna, disepakati pengawasan dilakukan oleh seluruh elemen masyarakat yang ada di Desa Olibuu.

Pos pengawasan dibangun ditempat strategis, tepat berada dipintu masuk Desa Olibuu, dan jalan masuk kewilayah hutan mangrove tempat satwa kelelawar menetap (simpang 3). Pos penjagaan ini berfungsi untuk pengawasan, selain itu berfungsi tempat pertemuan anggota kelompok, beristrahat bagi petani disekitar wilayah pos pengawasan. 


\section{KESIMPULAN}

Hutan manggrove yang berada di Pantai panjang didesa olibu ditetapkan sebagai lokasi Insitu. Pengawasan wilayah in-situ dilakukan oleh seluruh elemen masyarakat di pimpin langsung oleh Pemerintah desa dan Kelompok pemanfaat kelelawar. Penanaman tanaman buah di wilayah eks-situ dapat menjaga erosi tanah dan ketersediaan air tanah diwilayah DAS. Edukasi meningkatkan pengetahuan Kelompok Pemanfaat Kelelawar sehingga dicapai kesepakatan dasar tentang Konservasi Kelelawar yakni: Melarang Penebangan hutan bakau tanpa seizin pemerintah desa Olibu 1). Penangkapan kelelawar dilarang menggunakan senjata api atau sejenisnya yang menyebabkan kematian dan terganggunya habitat kelelawar dihutan Manggrove 2). Frekwensi menangkap kelelawar di lokasi in-situ dapat dilakukan $2 \times$ dalam seminggu, dengan cara menggunakan jaring atau net, dan dilakukan pada pukul 03.00 am -05.00 am 3). Kelelawar yang tertangkap harus disortasi, dengan kriteria: Kelelawar yang masih berumur muda/berukuran kecil, bunting dan Induk kelelawar yang mengasuh anak harus dilepaskan bersama anakknya kembali kehabitat hutan Manggrove 4)

\section{UCAPAN TERIMAKASIH}

Ucapan terimakasih disampaikan kepada Kementerian Ristek Dikti melalui Direktur Lembaga Penelitian dan Pengabdian atas Pendanaan Program Pengembagan Desa Mandiri (PPDM). Ucapan terimakasih juga kepada bapak Sulaiman Daima (Pemerintah Desa), masyarakat desa Olibu, dan mahasiswa KKS UNG 2019 atas kerjasama dalam program pengabdian

\section{DAFTAR PUSTAKA}

Arsyad, S. 2000. Pengawetan Tanah dan Air. Departemen IImu-IImu Tanah. Fakultas Pertanian. Institut Pertanian Bogor.

Departemen Pertanian, 2006. Peraturan Menteri Pertanian Nomor: 47/Permentan/ OT.140/10/2006 Tentang Pedoman Umum Budidaya Pertanian pada Lahan Pegunungan. Badan Litbang Pertanian, Departemen Pertanian
Febriani, Wenty Dwi and Saepuloh, Uus and Ayuningsih, Ellis Dwi and Saputra, R Suryo and Purbatrapsila, Azhari and Nangoy, Meis Jacinta and Ransaleh, Tiltje Andretha and Wahyuni, Indyah and Dako, Safriyanto and Noviana, Rachmitasari, 2018. Bat Coronavirus of Pteropus alecto from Gorontalo Province, Indonesia journal \{The International Journal of Tropical Veterinary and Biomedical Research\}, volume 3, no 2, hal 36-42, 2018

Hermanto dan Swatika. 2011. Penguatan Kelompok Tani: Langkah Awal Peningkatan Kesejahteraan Petani. Pusat Sosial Ekonomi dan Kebijakan Pertanian. Bogor.

Pamungkas J, Saputro S, Saepuloh U, Iskandriati D, Noviana $R$, Kristiyana $R$, Nangoy $M$, Ransaleleh T, Wahyuni I, Lomboan A, Dako S, Rakhwana, Siradjuddin R, Latinne A, Olival K. 2018. Surveillance for viruses in bats and rodents in Sulawesi. Proceedings of the International Conference of the Wildlife Disease Association Australasia (WDAA) In association with the Asian Society of Conservation Medicine : hal 43.

Kunz, T. H. dan E. D. Pierson. 1994. Bats of the world: an introduction. Pages 1-46 in R. W. Nowak, editor. Walker's bats of the world. John Hopkins University Press, Baltimore, USA.

Payne, J., Francis, C. M, Fhillipps, K. \& Kartikasari, S.N.(2000). Panduan Lapangan Mammalia di Kalimantan, Sabah, Serawak, dan Brunai Darussalam. Kuala Lumpur: The Sabah Society dan WWF Malaysia

Purvis, A., J. L. Gittleman, G. Cowlishaw, dan G. M. Mace. 2000. Predicting extinction risk in declining species. Proceedings of the Royal Society of London - Series B: Biological Sciences 267:1947-1952

Ransaleleh T, Maheswari RRA, Sugita $P$, dan Manalu W. 2013. Identifikasi Kelelawar Pemakan Buah Asal Sulawesi Berdasarkan Morfometri. Jurnal Veteriner Desember 2013 Vol. 14 No. 4: 485-494 ISSN : 1411 8327

Wulandari C. 2011. Agroforestry: Kesejahteraan Masyarakat dan Konservasi Sumberdaya Alam. Buku. Penerbit Universitas Lampung. $78 \mathrm{hlm}$. 